Article

\title{
Influence of Environmental Concern and Knowledge on Households' Willingness to Purchase Energy-Efficient Appliances: A Case Study in Shanxi, China
}

\author{
Guomin Li, Wei Li *, Zihan Jin and Zhihao Wang
}

School of Economics and Management, Taiyuan University of Technology; Taiyuan 030024, China; liguomin@tyut.edu.cn (G.L.); jinzihan0724@link.tyut.edu.cn (Z.J.); wangzhihao0787@link.tyut.edu.cn (Z.W.)

* Correspondence: liwei01@tyut.edu.cn; Tel.: +86-0351-317-6718

Received: 31 January 2019; Accepted: 14 February 2019; Published: 19 February 2019

check for updates

\begin{abstract}
With the increases in residents' household energy consumption and carbon emissions, to conserve regional energy and reduce emissions, studying the factors affecting residents' willingness to purchase energy-efficient appliances and their mechanisms of action is necessary. In this research, based on the theory of extended planned behavior and combined with environmental concern variables and environmental knowledge variables, a model of the factors influencing residents' willingness to purchase energy-efficient appliances was constructed and an empirical study of urban residents in Shanxi Province, China was conducted. The research indicates that environmental concern, environmental knowledge, attitude, and perceived behavioral control are significantly positively correlated with residents' willingness to purchase energy-efficient appliances. The influence of subjective norms on the willingness of residents to purchase energy-efficient appliances is not significant; environmental concern and environmental knowledge have a positive impact on attitudes and indirectly affect residents' willingness to purchase energy-efficient appliances. This study focuses on improvement and research from the perspectives of theoretical expansion, indirect impact test, and analysis of typical underdeveloped energy-rich regions. This study provides corresponding policy suggestions from the perspectives of education and guidance, sales and marketing, and independent improvement for the government, sellers, and residents, to improve the residents' willingness to purchase energy-efficient appliances.
\end{abstract}

Keywords: willingness to purchase; energy-efficient appliances; environmental concern; environmental knowledge; theory of planned behavior

\section{Introduction}

Increasing the willingness to purchase energy-efficient appliances is crucial for reducing household energy consumption and carbon emissions resulting from everyday consumption [1-3]. Appliances have become the main source of household energy consumption and carbon emissions, and their usage is growing rapidly. In China, household electric energy consumption increased by 468 billion $\mathrm{kWh}$ from 2005 to 2015 , an increase of $162 \%$. Studies have reported that household energy carbon emissions increased by $5.8 \%$ from 2014 to 2015, and household carbon emissions accounted for $11.6 \%$ of the total domestic carbon emissions, where about $70 \%$ of household carbon emissions are produced by household appliances [1]. The use of energy-efficient appliances has an important positive impact on reducing household energy consumption and household carbon emissions. According to statistics, in 2017, domestic energy-efficient appliances produced an annual electricity savings of about 10 billion $\mathrm{kWh}$, reducing carbon emissions by 6.5 million tons, which is a reduction of 14,000 tons 
of sulfur emissions, 14,000 tons of nitrogen oxide emissions, and 11,000 tons of particulate matter emissions [4].

Scholars have included other variables based on the theory of planned behavior to study the willingness to purchase energy-efficient appliances. These variables include subsidy policies [1], ethical norm $[5,6]$, price $[1,7,8]$, environmental concern, and environmental knowledge [9,10]. Studies have shown that subsidies have no significant impact on willingness to purchase, the effects of subsidy policies are limited, and short-term subsidies struggle to change purchasing habits of consumers [1]. Ethical norms have a significant impact on the willingness to purchase, but such changes require education with government promotion and take longer to achieve [5]. Price has a significant impact on the willingness to buy but such changes are affected by market changes and consumer preferences and are difficult to control $[7,11]$. Environmental concern and environmental knowledge also have a significant impact on the willingness to purchase and are closely related to the level of education of the residents and the popularity of publicity and education. Therefore, environmental concern and environmental knowledge can be enhanced by strengthening social publicity and environmental education, and are feasible and easy to implement [10].

Previous studies $[1,5,9,10,12-16]$ have explored the mechanism of action and impact intensity of environmental concern and environmental knowledge on the willingness to purchase energy-efficient products, laying a theoretical and methodological basis for clarifying the relationship between the above two factors. However, there is still room for further clarification and in-depth exploration.

Firstly, the existing studies on the relationship between the influencing factors and the purchase intention are not consistent, and there are large gaps. Specifically, previous studies in Egypt, Kuwait, Malaysia, India, China, Brazil, and other countries [1,9,10,12-15] have shown that environmental concern and environmental knowledge have a significant and positive impact on willingness to purchase. Tan et al. [5] and Ramayah et al. [16] showed that the relationship between the two is not significant. The reason for this inconsistency, shown by the comparison of these studies, is mainly due to two aspects: the differences in model construction and the differences in the research area.

Secondly, in terms of model construction, previous studies focused more on direct influences $[1,5,9,14]$. The indirect influence of environmental knowledge and environmental concern on purchase intention is ignored. The role of attitude as a mediating variable is neglected. This may lead to the underestimation of the effects of environmental concerns and environmental knowledge. Environmental knowledge and environmental concern may indirectly influence the willingness to purchase through environmental attitudes, and this impact should not be ignored [10,17].

Thirdly, in terms of study area, the impact of environmental knowledge and environmental concern on the willingness to purchase energy-efficient products varies with regional development level and endowment $[18,19]$. The existing studies mostly focused on developed regions in developed or developing countries [20]. The results in developed areas which cannot be directly used to guide the practice in less developed areas, especially in less developed energy-rich areas. The residents in developed areas have relatively high levels of economic development and higher education and environmental awareness. The developed areas usually have relatively higher population density, thus relatively tight energy supply, and relatively high demand for energy-saving appliances. Conversely, the situation is different for residents of less developed energy-rich areas. They have relatively adequate energy supplies, but limited purchasing power for energy-saving appliances [21]. Consequently, there is a greater need to improve the residents' willingness to purchase energy-efficient appliances in these regions by improving their environmental knowledge and awareness [22]. Unfortunately, fewer studies examined underdeveloped energy-rich regions. Therefore, the influencing mechanism of the willingness to purchase energy-efficient appliances in such regions needs to be further studied.

We aimed to examine whether a person's willingness to purchase energy-efficient appliances can be further explained by environmental concern and knowledge, in addition to the standard predictors of the theory of planned behavior (TPB) model. Both direct and indirect effects of the environmental 
concern and knowledge predictors on purchasing energy-efficient appliances were investigated in an attempt to expand the framework of the TPB. Shanxi Province, an underdeveloped energy-rich province in Central China, was taken as a sample area to provide reference for the promotion of energy-efficient appliances in energy-rich regions and promote residents' willingness to purchase energy-efficient appliances.

The remaining sections are organized as follows. Section 2 focuses on methodology, presenting the extended TBP, introducing our questionnaire design and survey, and describing statistical methods. Section 3 presents the results of hypothesis testing and effectiveness test (construct validity, convergent validity, and discriminant validity). The related discussion and the main conclusions are presented in Sections 4 and 5, respectively. The final section details a series of policy recommendations and outlines the limitations and future areas of research.

\section{Materials and Methods}

\subsection{Theoretical Basis}

The theory of planned behavior (TPB) was proposed by Ajzen in 1985 [23]. The basic theoretical model is that attitude (ATT), subjective norm (SN), and perceived behavioral control (PBC) affect behavioral will, thus influencing behavior. Through the application of the theory of planned behavior, Ajzen proposed adding new variables based on research problems, and then expanding the framework of the TPB by optimizing the model structure and variable paths [24].

Therefore, during studies of different problems, to explore the relationship among variables, scholars introduced some new variables based on the theory of planned behavior. For example, Yadav and Pathak [10] found that environmental concern (EC) and environmental knowledge (EK) have significant impacts on the willingness to purchase green products among young consumers when predicting the willingness of young consumers to purchase green products in developing countries. Some studies reported that tourists with high environmental concern tend to choose green hotels even if they need to pay a premium for the hotel's green practices $[25,26]$. According to the above analysis, scholars sometimes added EC and EK to the basic variables of the theory of planned behavior. However, the applicability of different research objects is open to question. Attempts to introduce EC and EK variables into the willingness of residents to purchase energy-efficient appliances may better explain the impacts of multiple variables on residents' willingness to purchase energy-efficient appliances.

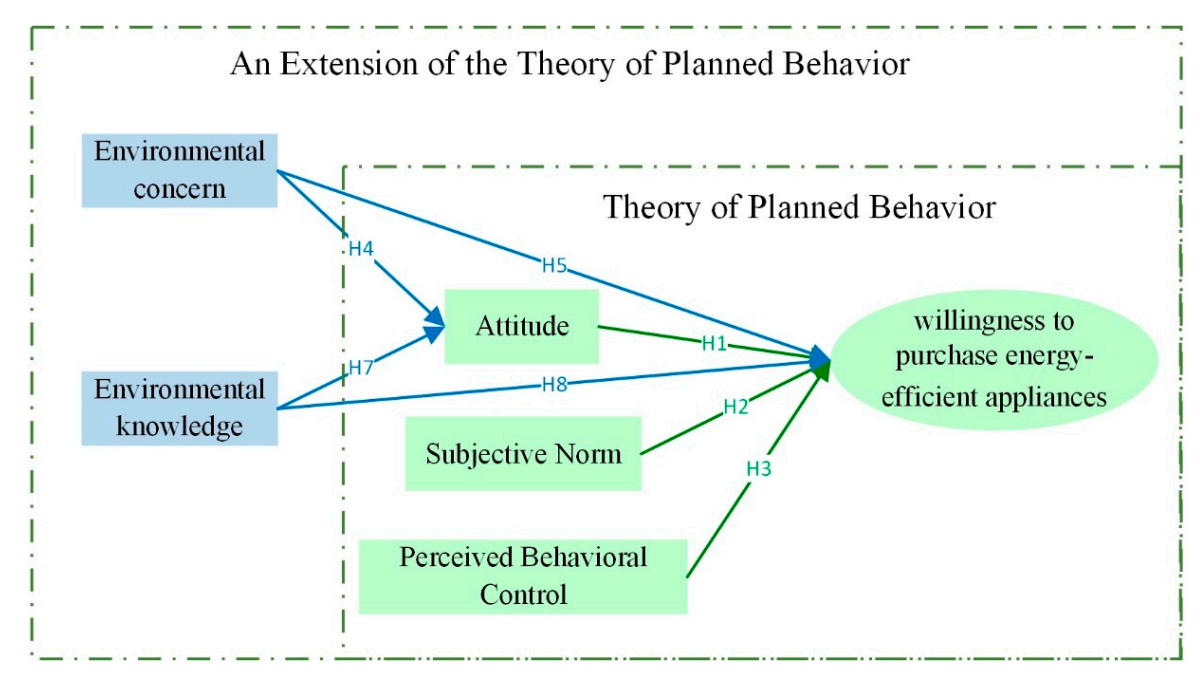

Figure 1. Model construction of the influencing factors of residents' willingness to purchase energy-efficient appliances (H1: the first hypothesis, H2: the second hypothesis, etc.). The detailed explanations of these hypothesis are provided in the next section. 
In summary, based on the theory of planned behavior, we introduce the variables, including environmental concern and environmental knowledge, used to construct the influencing factor model of residents' willingness to purchase energy-efficient appliances. The specific model construction is shown in Figure 1.

\subsection{Research Hypothesis}

Attitude refers to the stable psychological tendency of an individual for a particular behavior [24]. The better an individual's attitude toward a particular behavior, the greater the individual's tendency to perform this particular behavior [24,27]. This variable was introduced in studies focused on green product purchase behavior [28], electronic product recycling behavior [29], and energy-efficient behaviors [30]. Attitude has a stronger explanatory power, especially in studies on green product purchase behavior [31-33]. Since energy-efficient appliances are green products, the introduction of the attitude variable will also be significant. In summary, the following hypothesis is proposed:

H1. Attitude has a significant positive impact on residents' willingness to purchase energy-efficient appliances.

Subjective norm is the social pressure that an individual perceives when undertaking a particular behavior [24]. Social pressure mainly comes from the attitude or opinion, of others or groups who are important to a person, on whether the person should perform a particular behavior [34]. For example, if many people who are important to a person agree with certain behaviors, then the person is likely to perform such behavior. The greater the power from others' approval, the greater the likelihood that the person will perform the behavior [35]. For residents' willingness to purchase energy-efficient appliances, the subjective norm perceived by individuals is mainly sourced from family, friends, and public figures. When these people agree with or support the purchase of energy-efficient appliances, the individual will have a stronger willingness to implement the behavior. The role of social norms is related to behavior that is more or less open to others. The buying and using of these appliances will be mostly restricted to the home and will not be seen easily by others. As such, subjective norms have often less influence in this situation. Other studies in this field showed a low effect of this variable on behavior. In summary, the following hypothesis is introduced:

H2. Subjective norm has a significant positive impact on residents' willingness to purchase energy-efficient appliances.

Perceived behavioral control is the degree to which an individual expects to be able to control (or master) a particular undertaken behavior [24]: perceived behavioral control reflects the difficulty of whether an individual can use certain methods and opportunities to perform a certain behavior [36]. As a key factor, perceived behavioral control explains household waste recycling behavior and green food consumption behavior [37-39]. For the purchase of energy-efficient appliances, when individuals feel that the price of energy-efficient appliances is within their economic affordability, the barriers are often reduced, which adds to the willingness. In summary, the following hypothesis is proposed:

H3. Perceived behavioral control has a significant positive impact on residents' willingness to purchase energy-efficient appliances.

Environmental concern refers to the degree of people's willingness to recognize and support the resolution of ecological problems [40]. Environmental concern is an important factor affecting consumer spending decisions [41]. Studies have shown that environmental concern has a significant impact on residents' willingness to purchase [42-45]. Sang and Bekhet stated that consumers who are concerned about environmental issues are more willing to purchase electric vehicles [14]. Paul et al. reported the positive impact of environmental concern on the willingness to purchase green products [9]. Urban and Ščasný showed that residents who are more concerned about the environment have a higher tendency to carry out energy conservation and energy efficiency transformation [46]. Therefore, the willingness to purchase energy-efficient appliances is also affected by environmental concern [41]. 
Other studies also highlighted that environmental concern not only affects behavioral will but also influences the attitudes toward behavior; consumers with higher environmental concern tend to have a more positive environmental attitude, which in turn increases their willingness to act $[25,47,48]$. In summary, the following are hypothesized:

H4. Environmental concern has a significant positive impact on residents' attitudes toward purchasing energy-efficient appliances.

H5. Environmental concern has a significant positive impact on residents' willingness to purchase energy-efficient appliances.

H6. Attitude plays an intermediary role in the relationship between environmental concern and residents' willingness to purchase energy-efficient appliances.

Environmental knowledge refers to an individual's understanding and knowledge of the environment and related issues [49]. Individuals with certain environmental knowledge have a positive attitude toward environmental behavior and are strongly willing to take action. Flamm found that households with higher levels of environmental knowledge have a higher tendency to purchase energy-efficient cars [50]. Some scholars demonstrated that environmental knowledge has a positive impact on consumers' attitudes toward green products [13]. Latif et al. showed that environmental knowledge affects residents' attitudes toward green product purchase behavior, which in turn affects residents' willingness to purchase green products [14]. In summary, the following hypotheses are introduced:

H7. Environmental knowledge has a significant positive impact on residents' attitudes toward purchasing energy-efficient appliances.

H8. Environmental knowledge has a significant positive impact on residents' willingness to purchase energy-efficient appliances.

H9. Attitude plays an intermediary role in the relationship between environmental knowledge and residents' willingness to purchase energy-efficient appliances.

\subsection{Research Methods}

\subsubsection{Survey Design}

Based on the above theoretical analysis and research hypothesis, the willingness of residents to purchase energy-efficient appliances under the extended theory framework of planned behavior may be affected by five factors: environmental concern, environmental knowledge, attitude, subjective norms, and perceived behavioral control. Based on a comprehensive analysis and reference to existing scales, and after designing and making improvements based on the scales of the previous research results, the above five factors and their impact on residents' willingness to purchase energy-efficient appliances were further measured and examined. The scale used in this study includes three parts. The first part is the personal information part for collecting the basic information including sex, age, ethnicity, and education of the respondents. The second part is the measurement of the attitudes, subjective norms, perceived behavioral control, environmental concern, and environmental knowledge of residents toward energy-efficient appliances. The third part is the measurement of the willingness of residents to purchase energy-efficient appliances. The three parts contained a total of 25 items. The measurement contents of the second and third parts are shown in Table 1. In order to help the respondents better understand the research significance and research background, the survey begins with a brief introduction to energy-efficient appliances. For the answers to the questions, the Likert scale was used, where each respondent was required to fill in a number from " 1 " (strongly disagree) to " 5 " (strongly agree) to reflect the actual measurement. 
Table 1. Measurement and influencing factors of residents' willingness to purchase energy-efficient appliances.

\begin{tabular}{|c|c|c|}
\hline Latent Variable & Measurement Item & Source \\
\hline \multirow{4}{*}{$\begin{array}{l}\text { Attitude } \\
\text { (ATT) }\end{array}$} & ATT1: I think buying energy-efficient appliances is a very good practice & \multirow{4}{*}{ Kim and Han [20] } \\
\hline & ATT2: I think buying energy-efficient appliances is an ideal practice & \\
\hline & ATT3: I think buying energy-efficient appliances is a pleasant experience & \\
\hline & ATT4: I think buying energy-efficient appliances is a beneficial practice & \\
\hline \multirow{2}{*}{$\begin{array}{l}\text { Subjective Norm } \\
\text { (SN) }\end{array}$} & $\begin{array}{l}\text { SN1: Most people who are important to me want me to buy } \\
\text { energy-efficient appliances }\end{array}$ & \multirow{2}{*}{ Chan and Lau [49] } \\
\hline & $\begin{array}{l}\text { SN2: Most people who are important to me think that I should buy } \\
\text { energy-efficient appliances }\end{array}$ & \\
\hline \multirow{3}{*}{$\begin{array}{l}\text { Perceived Behavioral Control } \\
\text { (PBC) }\end{array}$} & $\begin{array}{l}\text { PBC1: Whether to buy energy-efficient appliances depends entirely on } \\
\text { my wishes }\end{array}$ & \multirow{3}{*}{ Kim and Han [26] } \\
\hline & $\begin{array}{l}\text { PBC2: I have the resources, time, and opportunity to buy energy-efficient } \\
\text { appliances }\end{array}$ & \\
\hline & $\begin{array}{l}\text { PBC3: I believe that if I want, I can buy energy-efficient appliances instead of } \\
\text { traditional appliances }\end{array}$ & \\
\hline \multirow{3}{*}{$\begin{array}{l}\text { Environmental Concern } \\
(\mathrm{EC})\end{array}$} & EC1: The natural balance is fragile and vulnerable to damage & \multirow{3}{*}{ Mostafa [13] } \\
\hline & $\begin{array}{l}\text { EC2: When nature is disturbed by humans, there are often } \\
\text { catastrophic consequences }\end{array}$ & \\
\hline & EC3: Human beings must live in harmony with nature in order to survive & \\
\hline \multirow{3}{*}{$\begin{array}{l}\text { Environmental Knowledge } \\
\text { (EK) }\end{array}$} & EK1: I can tell if the appliances I bought are good for the environment & \multirow{3}{*}{ Mostafa [12] } \\
\hline & EK2: I know more about recycling than other ordinary people & \\
\hline & EK3: I thoroughly know about environmental issues & \\
\hline \multirow{3}{*}{$\begin{array}{l}\text { Purchase Intention } \\
\text { (PI) }\end{array}$} & PI1: I can buy energy-efficient appliances (can) & \multirow{3}{*}{ Kim and Han [26] } \\
\hline & PI2: I am willing to buy energy-efficient appliances (am willing to) & \\
\hline & PI3: I will try my best to buy energy-efficient appliances (try one's best) & \\
\hline
\end{tabular}

\subsubsection{Data Collection}

The research objects were the urban residents in Shanxi Province, China. Shanxi Province, located in the middle of China (Figure 2), is a typical underdeveloped energy-rich region, with a low level of economic development, limited purchasing power of residents, and abundant reserves of natural resources, especially coal resources, which guarantees energy for residents. The research area is a typical area selected based on regional natural conditions and economic and social development, with certain specialness and representativeness. In terms of the changes in household energy consumption, the household electricity consumption in Shanxi province has increased rapidly. From 2013 to 2017, the proportion of residential electricity consumption in total domestic energy consumption increased from $27.6 \%$ to $33.3 \%$, an increase of $20 \%$ [4]. By taking the urban residents in Shanxi Province as the survey object, we were able to reflect the influence of potential factors, such as economic development level, residents' purchasing power, and household energy supply, on the willingness of urban residents to purchase energy-efficient appliances, thus providing an important reference for promoting the purchase and use of energy-efficient appliances in underdeveloped energy-rich regions. 


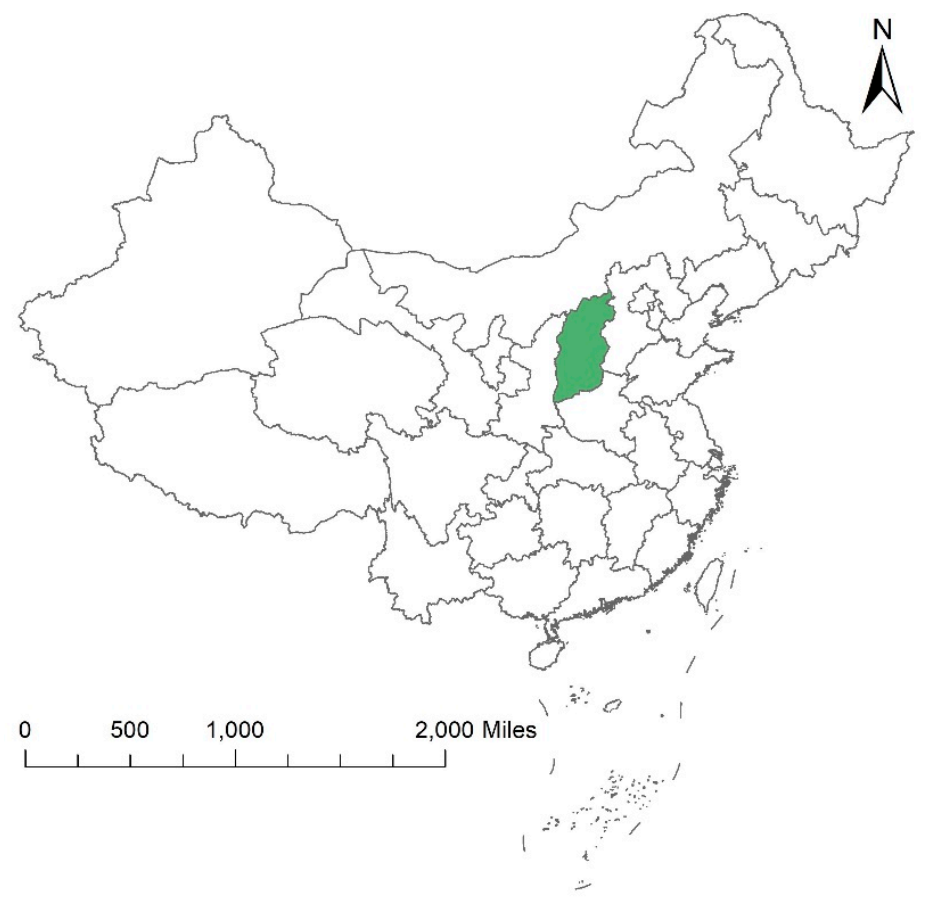

Figure 2. The location of the study area.

Considering the decision-making rights for home appliance purchase, the specific respondents were limited to residents who live in Shanxi Province and were at least 18 years of age. The survey method was a random on-site research, and the respondents filled in the answers according to their actual situations. The questionnaire survey was conducted from June 2018 to October 2018. A total of 331 questionnaires were distributed during the survey. After a screening, 305 valid questionnaires were collected.

The adoption of a case study methodology is justified by the exploratory and interpretative characters of our study [51]. China is a country with vast territory. Different regions have different geographical characteristics. Therefore, the use of case analysis with qualitative analysis is more conducive to this exploratory study to draw better conclusions. In the current study, only case studies in Beijing have been conducted in China, and there are obvious differences between Beijing and Shanxi. In view of this situation, it was appropriate to select Shanxi Province as a case to explore residents' willingness to purchase energy-saving household appliances [52].

The composition and distribution of the samples are shown in Table 2. According to the data in Table 2, the distribution of the samples in several attributes such as sex, age, and ethnicity was relatively consistent with the overall characteristics of Shanxi Province, but the distribution in the purchase of energy-saving electrical appliances, income, and education level was seemingly not consistent with the overall distribution of Shanxi Province. To be specific, too many samples accumulated around people who buy household appliances for festivals, high earners, or people with high educational background. In the future, the study could be improved by expanding the sample size. In order to isolate the impact of income and education, we statistically analyzed these variables as control variables, which, to some extent, compensated for the impact of sample bias.

Through descriptive statistical analysis of the sample, we found that $99.34 \%$ of consumers have purchased energy-efficient appliances in earlier purchase decisions. In terms of sex distribution, the number of male respondents was slightly higher than that of female respondents, accounting for $56.72 \%$ and $43.28 \%$, respectively. In terms of age distribution, $82.29 \%$ of the respondents were between 21 and 40 years old, of which $47.21 \%$ of the respondents were between 21 to 30 years old, and $35.08 \%$ of the respondents were between 31 to 40 years old. The vast majority of respondents were of Han nationality, and only a few respondents were ethnic minorities. Most of the respondents had a 
bachelor's degree, accounting for $68.85 \%$, and there were more married respondents than unmarried respondents. In terms of the income, the respondents with a monthly income of 5001 to 8000 yuan accounted for the highest proportion, which was $57.38 \%$ of the total, followed by respondents with incomes ranging from 2001 to 5000 yuan, or higher than 8000 yuan. The specific information is shown in Table 2:

Table 2. Distribution of samples.

\begin{tabular}{|c|c|c|c|}
\hline Variable Characteristics & Classification Standards & Frequency & Percent (\%) \\
\hline \multirow{2}{*}{$\begin{array}{l}\text { Ever purchased energy-efficient } \\
\text { household appliances }\end{array}$} & Yes & 303 & 99.34 \\
\hline & No & 2 & 0.66 \\
\hline \multirow{2}{*}{ Sex } & Male & 173 & 56.72 \\
\hline & Female & 132 & 43.28 \\
\hline \multirow{6}{*}{ Age } & $\leq 21$ & 3 & 0.98 \\
\hline & $21-30$ & 147 & 47.21 \\
\hline & $31-40$ & 107 & 35.08 \\
\hline & $41-50$ & 27 & 8.85 \\
\hline & $51-60$ & 20 & 6.56 \\
\hline & $\geq 61$ & 4 & 1.31 \\
\hline \multirow{2}{*}{ Nationality } & Han nationality & 303 & 99.34 \\
\hline & Ethnic minorities & 2 & 0.66 \\
\hline \multirow{5}{*}{ Monthly income } & Not stated & 20 & 6.56 \\
\hline & Below 2000 yuan & 13 & 4.26 \\
\hline & $2001-5000$ yuan & 60 & 19.67 \\
\hline & $5001-8000$ yuan & 175 & 57.38 \\
\hline & Above 8001 yuan & 37 & 12.13 \\
\hline \multirow{5}{*}{ Education } & High school and below & 31 & 10.16 \\
\hline & Junior college & 16 & 5.25 \\
\hline & Bachelor degree & 210 & 68.85 \\
\hline & master degree & 25 & 8.2 \\
\hline & Doctor degree or above & 23 & 7.54 \\
\hline \multirow{3}{*}{ Marital status } & Single & 29 & 9.51 \\
\hline & Married & 271 & 88.85 \\
\hline & Divorced & 5 & 1.64 \\
\hline
\end{tabular}

\subsubsection{Statistical Analysis}

To determine the effectiveness of the questionnaire items, four indicators-construct validity, convergent validity, discriminant validity, and reliability of the questionnaire-were analyzed to ensure the validity of the questionnaire survey. Construct validity is reflected by two parameters: factor loading and cross loading. Convergent validity is reflected by factor loading, combined reliability, and average variance extracted. Discriminant validity is revealed by the differences between extracted average variance and the correlation coefficients between variables. The reliability of the questionnaire is reflected by Cronbach's alpha coefficient and combined reliability. All the parameters were calculated using Smart PLS (Partial least squares) 3.0 software (SmartPLS GmbH, Boenningstedt, Germany).

To test the research hypotheses, the standardized path coefficients and their significance level were calculated by Smart PLS 3.0 to judge the validity of hypothesis. If the level of the $t$-test is smaller 
than the significance level of 0.05 , then the hypothesis is tenable. The standardized path coefficients reflect the influence degree of each factor. To improve the reliability of the results, SPSS (IBM, Armonk, NY, USA) macro INDIRECT and the bootstrap method were used to test the mediating effects ( $\mathrm{H} 6$ and H9) of the mediating variables and verify the significance of the mediating effects, respectively.

\section{Results}

\subsection{Construct Validity}

Construct validity is one of the important indicators that reflects the validity of the scale. Construct validity is used to reflect the confidence level of the sample measurements representing the overall true score [53]. In this study, Smart PLS 3.0 was used to measure the factor loading and cross loading of each item to test the construct validity of the scale. The measurement results show that the factor loading is larger than the cross loading.

By referring to Hair et al., a factor loading with a value above 0.50 is valid and that item should be retained [53]. Oppositely, if the factor loading value of the item is less than 0.50 , the item should be deleted. As shown in Table 3, the factor loading values of all the question items are higher than 0.50, which indicates that the scale used in this study had a high construct validity.

Table 3. Measurement results of convergence validity.

\begin{tabular}{|c|c|c|c|c|c|}
\hline Latent Variable & $\begin{array}{l}\text { Measurement } \\
\text { Item }\end{array}$ & Loading & $\begin{array}{l}\text { Cronbach's } \\
\text { Alpha }\end{array}$ & $\begin{array}{l}\text { Combined } \\
\text { Reliability }\end{array}$ & $\begin{array}{l}\text { Average Variance } \\
\text { Extracted }\end{array}$ \\
\hline \multirow{4}{*}{ Attitude (ATT) } & ATT1 & 0.872 & \multirow[t]{4}{*}{0.921} & \multirow[t]{4}{*}{0.944} & \multirow[t]{4}{*}{0.808} \\
\hline & ATT2 & 0.918 & & & \\
\hline & ATT3 & 0.898 & & & \\
\hline & ATT4 & 0.906 & & & \\
\hline \multirow{2}{*}{ Subjective Norm (SN) } & SN1 & 0.971 & \multirow[t]{2}{*}{0.881} & \multirow[t]{2}{*}{0.94} & \multirow[t]{2}{*}{0.887} \\
\hline & SN2 & 0.912 & & & \\
\hline \multirow{3}{*}{$\begin{array}{l}\text { Perceived Behavioral } \\
\text { Control (PBC) }\end{array}$} & PBC1 & 0.756 & \multirow[t]{3}{*}{0.742} & \multirow[t]{3}{*}{0.849} & \multirow[t]{3}{*}{0.653} \\
\hline & PBC2 & 0.842 & & & \\
\hline & PBC3 & 0.832 & & & \\
\hline \multirow{3}{*}{$\begin{array}{l}\text { Environmental } \\
\text { Concern (EC) }\end{array}$} & EC1 & 0.916 & \multirow[t]{3}{*}{0.909} & \multirow[t]{3}{*}{0.942} & \multirow[t]{3}{*}{0.844} \\
\hline & EC2 & 0.925 & & & \\
\hline & EC3 & 0.915 & & & \\
\hline \multirow{3}{*}{$\begin{array}{l}\text { Environmental } \\
\text { Knowledge (EK) }\end{array}$} & EK1 & 0.777 & \multirow[t]{3}{*}{0.718} & \multirow[t]{3}{*}{0.841} & \multirow[t]{3}{*}{0.638} \\
\hline & EK2 & 0.822 & & & \\
\hline & EK3 & 0.797 & & & \\
\hline \multirow{3}{*}{ Purchase Intention (PI) } & PI1 & 0.857 & \multirow[t]{3}{*}{0.795} & \multirow[t]{3}{*}{0.88} & \multirow[t]{3}{*}{0.711} \\
\hline & PI2 & 0.789 & & & \\
\hline & PI3 & 0.88 & & & \\
\hline
\end{tabular}

\subsection{Convergence Validity}

Convergence validity is a measure of how consistent the multiple items' measurements are on the same variable. In this study, factor loading, combined reliability (CR), and average variance extracted (AVE) were used to measure convergence validity [53-55]. The measurement results are shown in Table 3.

According to the calculation results in Table 3, the factor loading value of the items ranges between 0.756 and 0.971 , and the results are all higher than 0.7 . The measured values of the combined reliability are in the interval of 0.841 and 0.944 , above the minimum threshold 0.7 . The values of average variance extracted range from 0.653 to 0.887 , above the critical value of 0.5 [53,54]. These values indicate that the survey had a high convergence validity. 


\subsection{Discriminant Validity}

Discriminant validity indicates the degree to which a single variable is distinguished from other variables. Question items with different variables should not be highly correlated, and the correlations between different variables should be low. According to the Fornell-Larckers criterion, the square root of the average variance extracted (AVE) should be greater than the correlations between the variables [56,57]. As shown in Table 4, the bold text on the diagonal in the table represents the square root of the average variance extracted for each variable. The non-diagonal lines are the correlation coefficients between variables. Therefore, the overall measurement model of this study had sufficient discriminant validity.

Table 4. Measurement results of discriminant validity.

\begin{tabular}{lllllll}
\hline $\begin{array}{l}\text { Latent } \\
\text { Variable }\end{array}$ & $\begin{array}{l}\text { Attitude } \\
\text { (ATT) }\end{array}$ & $\begin{array}{l}\text { Environmental } \\
\text { Concern (EC) }\end{array}$ & $\begin{array}{l}\text { Environmental } \\
\text { knowledge (EK) }\end{array}$ & $\begin{array}{l}\text { Perceived Behavioral } \\
\text { Control (PBC) }\end{array}$ & $\begin{array}{l}\text { Purchase } \\
\text { Intention (PI) }\end{array}$ & $\begin{array}{l}\text { Subjective } \\
\text { Norm (SN) }\end{array}$ \\
\hline ATT & $\mathbf{0 . 8 9 9}$ & & & & & \\
EC & 0.317 & $\mathbf{0 . 9 1 9}$ & & & & \\
EK & 0.193 & 0.252 & $\mathbf{0 . 7 9 9}$ & 0.808 & & \\
PBC & 0.338 & 0.179 & 0.144 & 0.421 & 0.843 & \\
PI & 0.474 & 0.362 & 0.237 & 0.197 & 0.198 & $\mathbf{0 . 9 4 2}$ \\
SN & 0.089 & 0.251 & 0.141 & & & \\
\hline
\end{tabular}

\subsection{Reliability Test}

Scale reliability was measured using Cronbach's alpha coefficient and combined reliability. The reliability test results are shown in Table 3. As can be seen from Table 3, the Cronbach's alpha value of each variable is in the interval of 0.718 to 0.921 , and the $C R$ value ranges from 0.841 to 0.944 . Therefore, the scale had a high confidence level $[53,55,58]$.

In addition, regression analysis was conducted to examine the effect of education level and income on the results (as independent variables). The results showed that the effects of the two variables were not statistically significant.

\subsection{Hypothesis Analysis}

In this study, the action paths between variables were calculated using Smart PLS 3.0, and the research hypotheses were further analyzed, as shown in Table 5. Attitude, perceived behavioral control, environmental concern, and environmental knowledge had positive impacts on residents' willingness to purchase energy-efficient appliances; the standardized path coefficients are $0.306,0.262$, 0.177 , and 0.087 , respectively, and passed the analysis at a significance level of 0.01 or 0.05 . Therefore, $\mathrm{H} 1, \mathrm{H} 3, \mathrm{H} 5$, and $\mathrm{H} 8$ were verified.

Table 5. Action path coefficients between variables and their analysis results.

\begin{tabular}{ccccccc}
\hline Hypothesis & Relationship & Coefficient & Standard Error & $\boldsymbol{t}$-Value & $\boldsymbol{P}$-Value & Supported \\
\hline H1 & ATT $\rightarrow$ PI & 0.306 & 0.060 & 5.104 & 0.000 & Yes \\
H2 & SN $\rightarrow$ PI & 0.063 & 0.045 & 1.399 & 0.081 & No \\
H3 & PBC $\rightarrow$ PI & 0.262 & 0.059 & 4.426 & 0.000 & Yes \\
H4 & EC $\rightarrow$ ATT & 0.286 & 0.060 & 4.798 & 0.000 & Yes \\
H5 & EC $\rightarrow$ PI & 0.177 & 0.053 & 3.321 & 0.000 & Yes \\
H6 & EC $\rightarrow$ ATT $\rightarrow$ PI & 0.087 & 0.026 & 3.105 & 0.001 & Yes \\
H7 & EK $\rightarrow$ ATT & 0.125 & 0.049 & 2.567 & 0.005 & Yes \\
H8 & EK $\rightarrow$ PI & 0.087 & 0.043 & 1.992 & 0.023 & Yes \\
H9 & EK $\rightarrow$ ATT $\rightarrow$ PI & 0.041 & 0.017 & 2.211 & 0.027 & Yes \\
\hline
\end{tabular}

Environmental concern and environmental knowledge also had positive impacts on attitudes; the standardized path coefficients were 0.286 and 0.125 , and passed the analysis at the significance level of 0.01 . Therefore, $\mathrm{H} 4$ and $\mathrm{H} 7$ were verified. The standardized path coefficient of the subjective norm 
for residents' willingness to purchase energy-efficient appliances of 0.063 did not pass the significance analysis at the 0.05 level, so $\mathrm{H} 2$ was not verified.

The results of the intermediary effect are shown in Table 5 for H6 and H9. The T-values of the two paths are 3.105 and 2.211, respectively, and both passed the analysis. This proves that the intermediary effect exists and is significant [59]. Therefore, $\mathrm{H6}$ and $\mathrm{H} 9$ were verified.

To further accurately examine the role of mediating variables, the SPSS macro INDIRECT, developed by Preacher et al. [60], was introduced to test the mediating effects (H6 and H9) of mediating variables and Bootstrap method was used to verify the significance of mediating effects. This method estimates the indirect effects of the mediating variables and the sampling distribution characteristics through repeated random sampling. This method provides a confidence interval for the mediating effect. The independent variables, mediating variables, and dependent variables were added to the macro and bootstrap random sampling was set to 1000 times.

Table 6 exhibits the results. The data in Table 6 show that the partial mediating effects of attitude (M1, $\beta=0.0855, p<0.05 ; \mathrm{M} 2, \beta=0.0751, p<0.05$ ) are significant. The confidence intervals of the mediating variable do not contain zero. Therefore, $\mathrm{H} 6$ and $\mathrm{H} 9$ were supported by the data.

Table 6. Mediating effects.

\begin{tabular}{llll}
\hline \multirow{2}{*}{ Independent Variables } & \multicolumn{2}{l}{ Mediating Variable: ATT } \\
\cline { 2 - 4 } & Model 1 & Model 2 & Confidence Interval \\
\hline Environmental Concern & 0.0855 & & $0.0502,0.1282$ \\
\hline Environmental Knowledge & & 0.0751 & $0.0368,0.1271$ \\
\hline
\end{tabular}

\section{Discussion}

This study expanded upon the traditional theory of planned behavior and focused on the impact of environmental concerns and environmental knowledge on the purchase intention of urban residents for energy-efficient appliances. Before analyzing the influences of these two factors, we analyzed the influences of the main factors (attitude, subjective norms, and perceived behavior control) in traditional planned behavior theory.

In terms of attitude, based on the verification results of $\mathrm{H1}$, residents' attitudes toward the purchase of energy-efficient appliances are positively related to the willingness to purchase energy-efficient appliances, meaning the willingness of residents with positive attitudes toward purchasing energy-efficient appliances is stronger. Different scholars verified the above conclusions for different countries and regions, including Malaysia [5], India [10], Egypt [12], South Korea [26], and Chongqing [61]. From a regional perspective, although there are differences in energy types, both Chongqing and Shanxi are energy-rich regions. Therefore, there is a certain similarity in the attitudes affecting residents' willingness to purchase energy-efficient appliances. Based on relationship verification, some scholars proposed that the two are highly correlated, and this factor has become a necessary factor for predicting the purchasing behavior of energy-efficient appliances [62-64].

In terms of subjective norms, the results of this study show that the impact of subjective norms on residents' willingness to purchase energy-efficient appliances is not significant, which is consistent with the findings of Tan et al. [5]. However, some studies reported that subjective norms have a significant impact on residents' willingness to purchase energy-efficient appliances $[1,28]$. This is mainly due to regional economic conditions and cultural atmosphere. For example, the research results from Beijing [1] demonstrated that subjective norms have an impact on the willingness of residents to purchase energy-efficient appliances. Beijing has high levels of economic, social, and cultural development, and residents' awareness of energy conservation and environmental protection has been incorporated into their behavioral norms, which, in turn, helps to improve their willingness to purchase energy-efficient appliances. The different cultural atmospheres have led to the differences in residents' subjective norms. Therefore, underdeveloped areas, represented by Shanxi Province, should 
pay attention to green development and construction of a green cultural atmosphere to provide a more energy-saving cultural environment for residents in the region.

In terms of perceived behavioral control, the results of this study show that there is a significant positive correlation between perceived behavioral control and residents' willingness to purchase energy-efficient appliances, which is consistent with the results some previous research $[25,65]$. Therefore, the stronger the influence of perceived behavioral control, the higher the willingness to purchase. With the increase in people's purchasing power and the understanding of the utility of energy-efficient appliances, the willingness to purchase will increase, and a cycle will form [66]. Given the importance of this factor, Tan et al. showed that perceived behavioral control is the most important factor affecting residents' willingness to purchase energy-efficient appliances because residents are influenced by personal purchasing experience and their resources when purchasing energy-efficient appliances [5].

The results of the above variables are the extension from the past research on the basic variables of the theory of planned behavior. In this study, two variables-environmental concern and environmental knowledge-were added and further explored. The results show that environmental concern and knowledge both have a significant positive correlation with residents' willingness to purchase energy-efficient appliances. However, both have a relatively smaller effect coefficient on the purchase intention, which are obviously smaller than that of attitude and perceived behavior norms.

However, it is too early to draw the conclusion that environmental concern and knowledge have little influence on purchase intention. The verification results of $\mathrm{H} 6$ and $\mathrm{H} 9$ show that both environmental concern and knowledge can indirectly influence purchase intention through influencing attitude. This is consistent with the findings of Yadav and Pathak [10], Lu and Wang [67], and Chan et al. [68]. The effect coefficients of environmental concern and knowledge on attitude were 0.286 and 0.125 , respectively, both of which were greater than the direct effects of the two factors on purchase intention. This further corroborated that the effect of environmental concern and knowledge on purchase intentions has been underestimated in the studies considering only the direct effects. In related studies, the influences of environmental concern and knowledge on green behavior have been considered, further indicating the importance of the two factors. For instance, $\mathrm{Li}$ and $\mathrm{Hu}$ stated that environmental knowledge has a significant impact on the willingness to pay for improving regional air quality [69]. Taufique et al. thought that environmental knowledge promotion in the sales process is an important factor in promoting green consumer purchase behavior [70]. We conclude that environmental concern and knowledge will make residents more aware of the importance of energy conservation and emissions reduction, change their attitudes toward purchasing energy-efficient appliances, thus increasing their willingness to purchase energy-efficient appliances. Advocacy and education are important means of increasing environmental knowledge.

The above analysis shows that in Shanxi Province, a typical underdeveloped energy-rich area, environmental concern and knowledge have a significant positive regulating effect on the purchase intention of energy-efficient appliances of urban residents in the region. This regulating effect has important guiding significance for Shanxi Province in realizing green development in the future. Shanxi Province, as the country's main energy production base, has a single coal-based heavy-industry and high-energy-consuming industrial structure with the four pillars. With the comprehensive transformation of China's economy, transforming the industrial structure in Shanxi Province has been difficult. So, during the 11th and 12th Five-Year Plan, Shanxi's Gross Domestic Product (GDP) continued to grow negatively, causing it to became a region with a less-developed economy in the country. Due to the lack of economic development and the lack of motivation for the development of energy-efficient industries, improving the use of energy-efficient technologies for appliances remains difficult. Shanxi has had insufficient investment in education for many years, and the area did not reached national standards until 2017 (education accounts for 4\% of GDP) [71], which led to a lower level of knowledge among residents and the lack of understanding of environmental knowledge and energy-efficient appliances, thus increasing the difficulty of the formation of subjective norms of 
energy conservation and environmental protection. In the future, the underdeveloped energy-rich areas, represented by Shanxi Province, should pay attention to improving citizens' environmental concerns and knowledge through various methods such as policy guidance, cultural cultivation, and public opinion. This will help to promote the transformation of regional economic development toward being green and efficient.

\section{Conclusions}

Promoting the purchase and the use of energy-efficient appliances is important for improving the energy conservation and emission reduction of residents. Especially for underdeveloped energy-rich regions, increasing the willingness of residents to purchase energy-efficient home appliances is significant for regional economic development, energy-efficient technology improvement, and resource conservation. However, the influencing factors and the mechanism of influence involved are still unclear. Therefore, in this research, the urban residents in Shanxi Province were taken as the survey object, and we expanded the perspective of the theoretical framework of planned behavior by adding two variables: environmental concern and environmental knowledge, to construct a model for influencing factors of residents' willingness to purchase energy-efficient appliances. Through the preliminary research, questionnaire design, and survey, the impact mechanism was deeply analyzed. The main conclusions are as follows.

First, through the reliability and validity analysis and hypothesis testing of the model, we proved that the research on the influencing factors and the mechanism of the residents' willingness to purchase energy-efficient appliances under the extended framework of the theory of planned behavior has certain scientific applicability.

Second, environmental concern, environmental knowledge, attitudes, and perceived behavioral control all have significant impacts on and positive correlations with the residents' willingness to purchase energy-efficient appliances.

Third, for the degree of influence, attitudes have the strongest influence on residents' willingness to purchase energy-efficient appliances. The standardized path coefficient of attitude was 0.306 , followed by environmental concern, and then perceived behavioral control. The standardized path coefficients of both were higher than 0.2 , whereas the impact of environmental knowledge was small.

Fourth, environmental concern and environmental knowledge not only have a direct impact on residents' willingness to purchase energy-efficient appliances, but also have an indirect positive impact on the purchase intension through the mediating variable. The increase in residents' environmental concern and environmental knowledge will further improve residents' purchase intension by affect the residents' attitudes toward energy-efficient appliances.

\section{Policy Suggestions}

Based on the analysis of the mechanism of the influencing factors on urban residents' willingness to buy energy-efficient appliances, policy suggestions are proposed from perspectives including education and guidance, sales and marketing, and independent improvement. Independent improvement is the foundation, sales and marketing are the medium, and education and guidance are the driving forces. The three complement one another and are indispensable. The interaction and contents of these policy suggestions are shown in Figure 3. 


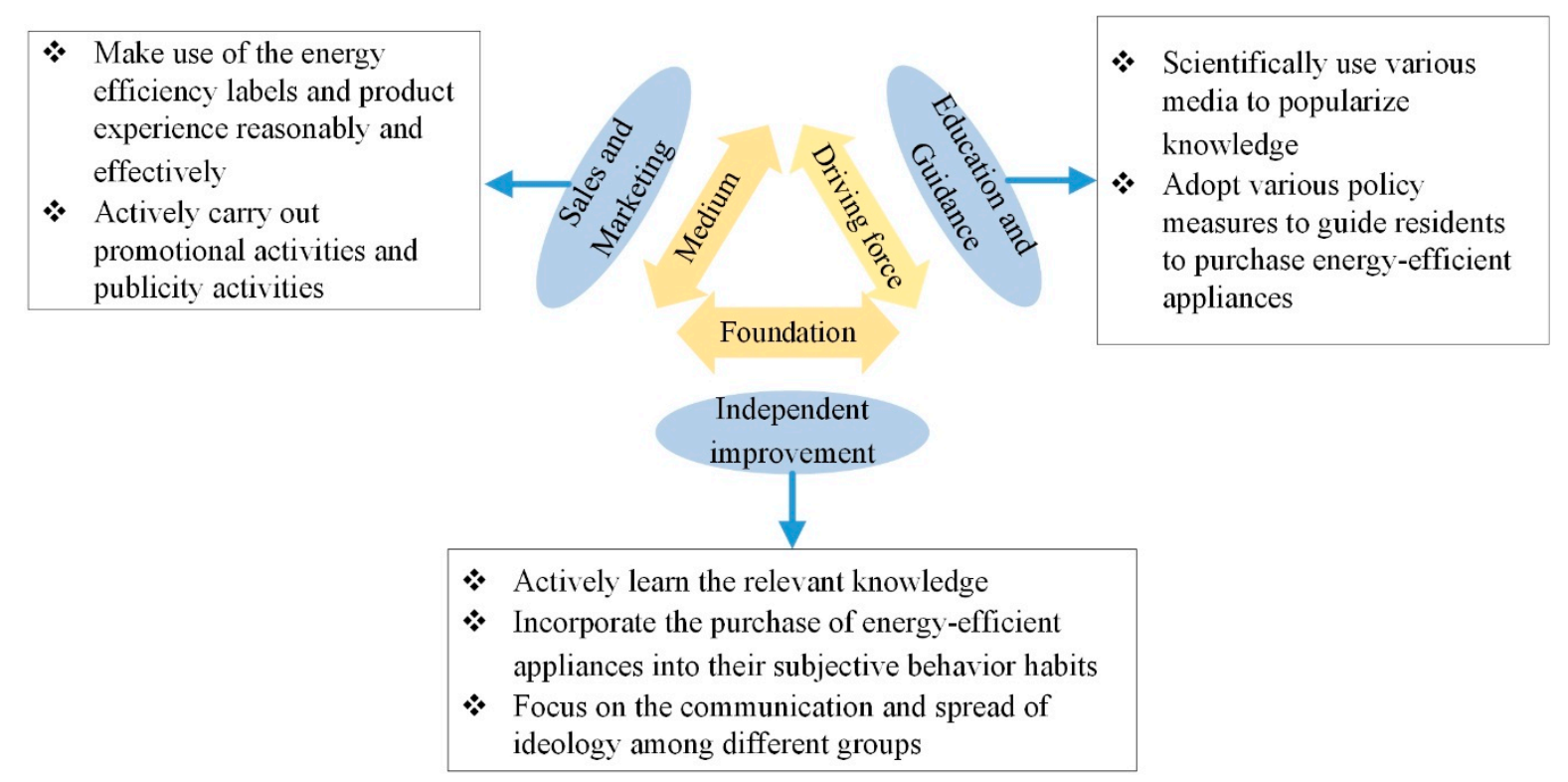

Figure 3. Framework and content of policy suggestions.

First is independent improvement. According to the H1, which was confirmed, attitude has a significant impact on the residents' willingness to purchase energy-efficient appliances, and attitude has the highest degree of influence. Therefore, residents should actively cultivate and improve their willingness to purchase energy-efficient appliances, actively learn the relevant information about energy-efficient appliances, and incorporate the purchase of energy-efficient appliances into their subjective behavior habits. It is necessary to focus on the communication and spread of ideology among different groups to promote the influence of such energy-efficient behaviors, thus forming the awareness of the general public.

Second are sales and marketing. According to H3, which was confirmed, perceived behavioral control has a significant impact on the residents' willingness to purchase energy-efficient appliances. Therefore, sellers should reasonably and effectively make use of the energy efficiency labels and product experience, so that residents can better understand the energy-efficient effect when purchasing energy-efficient appliances. Second, sellers should actively undertake promotional activities and publicity activities to give appropriate discounts under the reasonable conditions, spread knowledge about energy-efficient appliances to residents during actual sales, and elaborate upon its functions, quality, and operation procedures, thus enhancing residents' understanding and recognition on energy-efficient appliances. Private enterprises have relatively strong innovation ability in marketing [72]. Private enterprises should be encouraged to use advertising and brands to enhance the popularization and promotion of energy-saving appliances.

Third are education and guidance. According to the $\mathrm{H} 6$ and $\mathrm{H} 9$, which were confirmed, environmental concern and environmental knowledge not only impact residents' willingness to purchase energy-efficient appliances but also their attitudes toward purchasing these appliances. Having one of the main roles in promoting the willingness of residents to purchase energy-efficient appliances, the government should promote education. Consequently, it is necessary to widely educate about the importance of energy conservation and emission reduction among residents in society, scientifically use various media to popularize knowledge about energy-efficient appliances and environmental protection, thus further changing residents' attitudes toward energy-efficient appliances and enhancing their willingness to make these purchases independently. According to $\mathrm{H} 3$, the government should adopt various regulation measures to guide residents to purchase energy-efficient appliances [73], and fully exert their influence of perceived behavioral control on residents' willingness to purchase energy-efficient appliances. A subsidy policy on energy-efficient effect levels indicates that the better the energy-efficient effect, the higher the subsidy level. So, 
this type of policy can effectively prevent the refusal to purchase energy-efficient appliances due to price. From the perspective of negative incentives, charging extra fees for high-energy-consumption, high-pollution appliances, and increasing the cost of purchasing such appliances also reduce residents' willingness to purchase non-energy-efficient appliances

The conclusions in this paper are only preliminary. More work using more data from larger survey samples and the application of alternative statistical methods to verify hypotheses are clearly needed. Different regions can be compared to reflect the differences and causes and factors influencing residents' willingness to purchase energy-efficient appliances in different regions. Finally, the results of this paper indicate that the change in residents' willingness is long-lasting, continuous, and gradual. Therefore, future research should focus on behavioral experiment methods, and explore more subtle variables and factors from the perspective of dynamic changes based on continuous tracking research.

Author Contributions: G.L. contributed to the study design and drafting of the manuscript. W.L. reviewed and edited the manuscript. Z.J. and Z.W. implemented the questionnaire investigation and analyzed the data.

Funding: Shanxi Provincial Education Department: 2018JG24; The ShanXi Science and Technology Department: 2017041006-5; Shanxi Planning Office of Philosophy and Social Sciences: 2018B024; National Natural Science Foundation of China: 71373170; Shanxi Federation of Social Sciences: SSKLZDKT2018023.

Conflicts of Interest: The authors declare no conflict of interest.

\section{References}

1. Wang, Z.H.; Wang, X.M.; Guo, D.X. Policy implications of the purchasing intentions towards energy-efficient appliances among China's urban residents: Do subsidies work? Energy Policy 2017, 102, 430-439. [CrossRef]

2. Baldini, M.; Trivella, A.; Wente, J.W. The impact of socioeconomic and behavioural factors for purchasing energy efficient household appliances: A case study for Denmark. Energy Policy 2018, 120, 503-513. [CrossRef]

3. Nguyen, T.N.; Lobo, A.; Greenland, S. The influence of Vietnamese consumers' altruistic values on their purchase of energy efficient appliances. Asia Pac. J. Mark. Logist. 2017, 29, 759-777. [CrossRef]

4. National Development and Reform Commission. China's Resident Consumption Development Report 2017; People's Publishing House: Beijing, China, 2018; pp. 26-37.

5. Tan, C.S.; Ooi, H.Y.; Goh, Y.N. A moral extension of the theory of planned behavior to predict consumers' purchase intention for energy-efficient household appliances in Malaysia. Energy Policy 2017, 107, 459-471. [CrossRef]

6. Botetzagias, I.; Dima, A.F.; Malesios, C. Extending the Theory of Planned Behavior in the context of recycling: The role of moral norms and of demographic predictors. Resour. Conserv. Recycl. 2015, 95, 58-67. [CrossRef]

7. Pan, J.Y.; Truong, D. Passengers' intentions to use low-cost carriers: An extended theory of planned behavior model. J. Air Transp. Manag. 2018, 69, 38-48. [CrossRef]

8. de Medeiros, J.F.; Ribeiro, J.L.D.; Cortimiglia, M.N. Influence of perceived value on purchasing decisions of green products in Brazil. J. Clean. Prod. 2016, 110, 158-169. [CrossRef]

9. Paul, J.; Modi, A.; Patel, J. Predicting green product consumption using theory of planned behavior and reasoned action. J. Retail. Consum. Serv. 2016, 29, 123-134. [CrossRef]

10. Yadav, R.; Pathak, G.S. Young consumers' intention towards buying green products in a developing nation: Extending the theory of planned behavior. J. Clean. Prod. 2016, 135, 732-739. [CrossRef]

11. Ho, J.W.; Huang, Y.S.; Hsu, C.L. Pricing under internal and external competition for remanufacturing firms with green consumers. J. Clean. Prod. 2018, 202, 150-159. [CrossRef]

12. Mostafa, M.M. A hierarchical analysis of the green consciousness of the Egyptian consumer. Psychol. Mark. 2007, 24, 445-473. [CrossRef]

13. Mostafa, M.M. Shades of green: A psychographic segmentation of the green consumer in Kuwait using self-organizing maps. Expert Syst. Appl. 2009, 36, 11030-11038. [CrossRef]

14. Sang, Y.N.; Bekhet, H.A. Modelling electric vehicle usage intentions: An empirical study in Malaysia. J. Clean. Prod. 2015, 92, 75-83. [CrossRef]

15. Junior, S.S.B.; da Silva, D.; Gabriel, M.L.D.S.; de Oliveira Braga, W.R. The Effects of Environmental Concern on Purchase of Green Products in Retail. Procedia-Soc. Behav. Sci. 2015, 170, 99-108. [CrossRef] 
16. Ramayah, T.; Lee, J.W.C.; Mohamad, O. Green product purchase intention: Some insights from a developing country. Resour. Conserv. Recycl. 2010, 54, 1419-1427. [CrossRef]

17. Latif, S.A.; Omar, M.S.; Bidin, Y.H.; Awang, Z. Role of Environmental Knowledge in Creating Pro-Environmental Residents. In Proceedings of the Asia Pacific International Conference on Environment-Behaviour Studies, London, UK, 4-6 September 2013; Abbas, M.Y., Ed.; Elsevier Science Bv: Amsterdam, the Netherlands, 2013; Volume 105, pp. 866-874. [CrossRef]

18. Blair, B.D.; Crago, J.P.; Hedman, C.J.; Klaper, R.D. Pharmaceuticals and personal care products found in the Great Lakes above concentrations of environmental concern. Chemosphere 2013, 93, 2116-2123. [CrossRef] [PubMed]

19. Zsoka, A.; Szerenyi, Z.M.; Szechy, A.; Kocsis, T. Greening due to environmental education? Environmental knowledge, attitudes, consumer behavior and everyday pro-environmental activities of Hungarian high school and university students. J. Clean. Prod. 2013, 48, 126-138. [CrossRef]

20. Fang, W.T.; Lien, C.Y.; Huang, Y.W.; Han, G.S.; Shyu, G.S.; Chou, J.Y.; Ng, E. Environmental Literacy on Ecotourism: A Study on Student Knowledge, Attitude, and Behavioral Intentions in China and Taiwan. Sustainability 2018, 10, 1886. [CrossRef]

21. Du, P.; Chen, B.F. An Empirical Study on Farmers' Consumer Intention for Agriculture Machinery Operations Demand in Shanxi Province. In Proceedings of the 2011 International Conference on Management Science and Engineering-18th Annual Conference Proceedings, Vols I and Ii, Rome, Italy, 13-15 September 2011; Lan, H., Yang, Y.H., Eds.; IEEE: New York, NY, USA, 2011; pp. 1333-1338.

22. Mohiuddin, M.; Al Mamun, A.; Syed, F.A.; Masud, M.M.; Su, Z. Environmental Knowledge, Awareness, and Business School Students' Intentions to Purchase Green Vehicles in Emerging Countries. Sustainability 2018, 10, 1534. [CrossRef]

23. Ajzen, I. Perceived Behavioral Control, Self-Efficacy, Locus of Control, and the Theory of Planned Behavior1. J. Appl. Soc. Psychol. 2002, 32, 665-683. [CrossRef]

24. Ajzen, I. The theory of planned behavior. Organ. Behav. Hum. Decis. Process. 1991, 50, 179-211. [CrossRef]

25. Chen, M.-F.; Tung, P.-J. Developing an extended Theory of Planned Behavior model to predict consumers' intention to visit green hotels. Int. J. Hosp. Manag. 2014, 36, 221-230. [CrossRef]

26. Han, H. Intention to pay conventional-hotel prices at a green hotel-A modification of the theory of planned behavior AU-Kim, Yunhi. J. Sustain. Tour. 2010, 18, 997-1014. [CrossRef]

27. Han, H.; Hsu, L.-T.; Sheu, C. Application of the Theory of Planned Behavior to green hotel choice: Testing the effect of environmental friendly activities. Tour. Manag. 2010, 31, 325-334. [CrossRef]

28. Ha, H.Y.; Janda, S. Predicting consumer intentions to purchase energy-efficient products. J. Consum. Mark. 2012, 29, 461-469. [CrossRef]

29. Wang, Z.H.; Zhang, B.; Li, G. Determinants of energy-saving behavioral intention among residents in Beijing: Extending the theory of planned behavior. J. Renew. Sustain. Energy 2014, 6, 17. [CrossRef]

30. Wang, Z.H.; Zhang, B.; Yin, J.H.; Zhang, Y.X. Determinants and policy implications for household electricity-saving behaviour: Evidence from Beijing, China. Energy Policy 2011, 39, 3550-3557. [CrossRef]

31. Greaves, M.; Zibarras, L.D.; Stride, C. Using the theory of planned behavior to explore environmental behavioral intentions in the workplace. J. Environ. Psychol. 2013, 34, 109-120. [CrossRef]

32. Olsen, N.V.; Sijtsema, S.J.; Hall, G. Predicting consumers' intention to consume ready-to-eat meals. The role of moral attitude. Appetite 2010, 55, 534-539. [CrossRef]

33. Lee, T.S.; Md Ariff, M.S.; Zakuan, N.; Sulaiman, Z. Assessing Website Quality Affecting Online Purchase Intention of Malaysia's Young Consumers. Adv. Sci. Eng. Med. 2016, 8, 836-840. [CrossRef]

34. Park, H.S. Relationships among attitudes and subjective norms: Testing the theory of reasoned action across cultures. Commun. Stud. 2000, 51, 162-175. [CrossRef]

35. Conner, M.; Armitage, C.J. Extending the Theory of Planned Behavior: A Review and Avenues for Further Research. J. Appl. Soc. Psychol. 1998, 28, 1429-1464. [CrossRef]

36. Ajzen, B.I. Attitudes, Personality and Behaviour; McGraw-Hill Education: New York, NY, USA, 2005.

37. de Leeuw, A.; Valois, P.; Seixas, R. Understanding High School Students' Attitude, Social Norm, Perceived Control and Beliefs to Develop Educational Interventions on Sustainable Development. In Proceedings of the 3rd Cyprus International Conference on Educational Research, Lefkosa, Cyprus, 30 January-1 February 2014; Uzunboylu, H., Ed.; Elsevier Science Bv: Amsterdam, The Netherlands, 2014; Volume 143, pp. 1200-1209. [CrossRef] 
38. Tonglet, M.; Phillips, P.S.; Read, A.D. Using the Theory of Planned Behaviour to investigate the determinants of recycling behaviour: A case study from Brixworth, UK. Resour. Conserv. Recycl. 2004, 41, 191-214. [CrossRef]

39. Vermeir, I.; Verbeke, W. Sustainable food consumption among young adults in Belgium: Theory of planned behaviour and the role of confidence and values. Ecol. Econ. 2008, 64, 542-553. [CrossRef]

40. McCright, A.M.; Xiao, C.; Dunlap, R.E. Political polarization on support for government spending on environmental protection in the USA, 1974-2012. Soc. Sci. Res. 2014, 48, 251-260. [CrossRef]

41. Diamantopoulos, A.; Schlegelmilch, B.B.; Sinkovics, R.R.; Bohlen, G.M. Can socio-demographics still play a role in profiling green consumers? A review of the evidence and an empirical investigation. J. Bus. Res. 2003, 56, 465-480. [CrossRef]

42. Hartmann, P.; Apaolaza-Ibáñez, V. Consumer attitude and purchase intention toward green energy brands: The roles of psychological benefits and environmental concern. J. Bus. Res. 2012, 65, 1254-1263. [CrossRef]

43. Newton, J.D.; Tsarenko, Y.; Ferraro, C.; Sands, S. Environmental concern and environmental purchase intentions: The mediating role of learning strategy. J. Bus. Res. 2015, 68, 1974-1981. [CrossRef]

44. Rhead, R.; Elliot, M.; Upham, P. Assessing the structure of UK environmental concern and its association with pro-environmental behaviour. J. Environ. Psychol. 2015, 43, 175-183. [CrossRef]

45. Arisal, I.; Atalar, T. The Exploring Relationships between Environmental Concern, Collectivism and Ecological Purchase Intention. In Proceedings of the 12th International Strategic Management Conference (ISMC 2016), Antalya, Turkey, 28-30 October 2016; Ozsahin, M., Ed.; Elsevier Science Bv: Amsterdam, The Netherlands, 2016; Volume 235, pp. 514-521. [CrossRef]

46. Urban, J.; Scasny, M. Exploring domestic energy-saving: The role of environmental concern and background variables. Energy Policy 2012, 47, 69-80. [CrossRef]

47. Kalafatis, S.P.; Pollard, M.; East, R.; Tsogas, M.H. Green marketing and Ajzen's theory of planned behaviour: A cross-market examination. J. Consum. Mark. 1999, 16, 441-460. [CrossRef]

48. Clark, C.F.; Kotchen, M.J.; Moore, M.R. Internal and external influences on pro-environmental behavior: Participation in a green electricity program. J. Environ. Psychol. 2003, 23, 237-246. [CrossRef]

49. Chan, R.Y.K.; Lau, L.B.Y. Antecedents of green purchases: A survey in China. J. Consum. Mark. 2000, 17, 338-357. [CrossRef]

50. Flamm, B. The impacts of environmental knowledge and attitudes on vehicle ownership and use. Transp. Res. Part D Transp. Environ. 2009, 14, 272-279. [CrossRef]

51. Berardi, U. Stakeholders' influence on the adoption of energy-saving technologies in Italian homes. Energy Policy 2013, 60, 520-530. [CrossRef]

52. Albino, V.; Berardi, U. Green Buildings and Organizational Changes in Italian Case Studies. Bus. Strategy Environ. 2012, 21,387-400. [CrossRef]

53. Hair, J.F., Jr.; Hult, G.T.M.; Ringle, C.; Sarstedt, M. A Primer on Partial Least Squares Structural Equation Modeling (PLS-SEM), 2nd ed.; Sage Publications, Inc.: Thousand Oaks, CA, USA, 2017; Chapters 6-7.

54. Durdyev, S.; Ismail, S.; Ihtiyar, A.; Abu Bakar, N.F.S.; Darko, A. A partial least squares structural equation modeling (PLS-SEM) of barriers to sustainable construction in Malaysia. J. Clean. Prod. 2018, 204, 564-572. [CrossRef]

55. Ringle, C.M.; Sarstedt, M. PLS-SEM: Indeed a Silver Bullet AU-Hair, Joe F. J. Mark. Theory Pract. 2011, 19, 139-152. [CrossRef]

56. Henseler, J.; Ringle, C.M.; Sarstedt, M. A new criterion for assessing discriminant validity in variance-based structural equation modeling. J. Acad. Mark. Sci. 2015, 43, 115-135. [CrossRef]

57. Fornell, C.; Larcker, D.F. Evaluating Structural Equation Models with Unobservable Variables and Measurement Error. J. Mark. Res. 1981, 18, 39-50. [CrossRef]

58. Maziriri, E.T.; Madinga, N.W. Data to model the prognosticators of luxury consumption: A partial least squares-structural equation modelling approach (PLS-SEM). Data Brief 2018, 21, 753-757. [CrossRef]

59. Nitzl, C.; Roldan, J.L.; Cepeda, G. Mediation analysis in partial least squares path modeling Helping researchers discuss more sophisticated models. Ind. Manag. Data Syst. 2016, 116, 1849-1864. [CrossRef]

60. Preacher, K.J.; Hayes, A.F. SPSS and SAS procedures for estimating indirect effects in simple mediation models. Behav. Res. Methods Instrum. Comput. 2004, 36, 717-731. [CrossRef]

61. Ma, G.; Andrews-Speed, P.; Zhang, J.D. Chinese consumer attitudes towards energy saving: The case of household electrical appliances in Chongqing. Energy Policy 2013, 56, 591-602. [CrossRef] 
62. Lopez-Mosquera, N.; Garcia, T.; Barrena, R. An extension of the Theory of Planned Behavior to predict willingness to pay for the conservation of an urban park. J. Environ. Manag. 2014, 135, 91-99. [CrossRef]

63. Pothitou, M.; Hanna, R.F.; Chalvatzis, K.J. Environmental knowledge, pro-environmental behaviour and energy savings in households: An empirical study. Appl. Energy 2016, 184, 1217-1229. [CrossRef]

64. Jaiswal, D.; Kant, R. Green purchasing behaviour: A conceptual framework and empirical investigation of Indian consumers. J. Retail. Consum. Serv. 2018, 41, 60-69. [CrossRef]

65. Albayrak, T.; Aksoy, S..; Caber, M. The effect of environmental concern and scepticism on green purchase behaviour. Mark. Intell. Plan. 2013, 31, 27-39. [CrossRef]

66. Alam, S.S.; Hashim, N.H.N.; Rashid, M.; Omar, N.A.; Ahsan, N.; Ismail, M.D. Small-scale households renewable energy usage intention: Theoretical development and empirical settings. Renew. Energy 2014, 68, 255-263. [CrossRef]

67. Lu, J.L.; Wang, C.Y. Investigating the impacts of air travellers' environmental knowledge on attitudes toward carbon offsetting and willingness to mitigate the environmental impacts of aviation. Transp. Res. Part D Transp. Environ. 2018, 59, 96-107. [CrossRef]

68. Chan, E.S.W.; Hon, A.H.Y.; Chan, W.; Okumus, F. What drives employees' intentions to implement green practices in hotels? The role of knowledge, awareness, concern and ecological behaviour. Int. J. Hosp. Manag. 2014, 40, 20-28. [CrossRef]

69. Li, Z.T.; Hu, B. Perceived health risk, environmental knowledge, and contingent valuation for improving air quality: New evidence from the Jinchuan mining area in China. Econ. Hum. Biol. 2018, 31, 54-68. [CrossRef] [PubMed]

70. Taufique, K.M.R.; Siwar, C.; Chamhuri, N.; Sarah, F.H. Integrating General Environmental Knowledge and Eco-Label Knowledge in Understanding Ecologically Conscious Consumer Behavior. In Proceedings of the Fifth International Conference on Marketing and Retailing, Penang, Malaysia, 12-13 October 2015; Rashid, W.E.W., Muda, M., Eds.; Elsevier Science Bv: Amsterdam, The Netherlands, 2015; Volume 37, pp. 39-45. [CrossRef]

71. Department of Finance, Ministry of Education. China Educational Finance Statistical Yearbook 2017; China Statistics Press: Beijing, China, 2018; pp. 30-35.

72. Martins, A.C.; Marques, R.C.; Cruz, C.O. Public-private partnerships for wind power generation: The Portuguese case. Energy Policy 2011, 39, 94-104. [CrossRef]

73. Simoes, P.; Marques, R.C. Influence of regulation on the productivity of waste utilities. What can we learn with the Portuguese experience? Waste Manag. 2012, 32, 1266-1275. [CrossRef] [PubMed] 